\title{
"MY CHILDREN ... SHALL STRIKE THEIR ROOTS INTO UNACCUSTOMED EARTH": REPRESENTATION OF DIASPORIC BENGALIS IN JHUMPA LAHIRI'S LATEST COLLECTION OF STORIES
}

\author{
Human nature will not flourish, any more than a potato, \\ if it be planted and replanted, for too long a series of \\ generations, in the same worn-out soil. My children have \\ had other birthplaces, and, so far as their fortunes may \\ be within my control, shall strike their roots into \\ unaccustomed earth."
}

With the publication of Unaccustomed Earth (2008) Jhumpa Lahiri has returned to short stories yet again. ${ }^{2}$ This collection of eight stories, her latest, takes its title from the above-quoted passage in Nathaniel Hawthorne's Introduction to The Scarlet Letter. This Hawthorne-passage - with its unmistakable existential thesis and diasporic overtone seems to be particularly relevant to her subject. Lahiri herself is reported to have said that she was struck when she read Hawthorne's words: "I just thought about how much they stand for everything that I had been writing about: the experience of being transplanted, and people being transplanted." ${ }^{3}$ Lahiri however does not so much accept Hawthorne's notion as test it since her stories seem to suggest that while human fortune improves if men and women "strike their roots into unaccustomed earth," any such experiment of transplanting involves the plant in diverse complex consequences as well.

Tasha Robinson in her review of Unaccustomed Earth calls the book "a symphony of eight movements," since all the eight stories of Unaccustomed Earth, despite being divided into two sections, are engaged with similar set of themes and characters. This paper seeks to explore the major themes and issues which link Lahiri's latest work to her only

\footnotetext{
' Nathaniel Hawthorne. "The Custom-House." The Scarlet Letter. Oxford: OUP, 1990 (World Classic Paperback Edition). 11-12. emphasis mine.

${ }^{2}$ After her debut short story collection Interpreter of Maladies (1999) Lahiri published her only novel The Namesake in 2003.

${ }^{3}$ Elena Seibert. "Strained Connections in Unaccustomed Earth." 11 May 2010. $<$ http://www.npr.org/templates/story/story.php?storyld=90121534>.

${ }^{4}$ Tasha Robinson. "Review of Unaccustomed Earth." 30 Jan. 2010.
} $<$ http://www.avclub.com/content/words/unaccustomed_earth $>$. 
novel The Namesake (2003) and her debut collection of stories Interpreter of Maladies (1999). ${ }^{5}$ With special focus on different facets of Lahiri's representation of diasporic Bengalis $^{6}$ in the USA and their cultural markers, the paper aims to engage with intergenerational conflicts and anguished self-divisions among both the first and secondgeneration immigrants who inhabit the no-man's land between integration and resistant memories/inherited mores of the abandoned "home."

Unaccustomed Earth revolves around Lahiri's familiar terrain, her "two-inches of ivory": the community of (upper)middle-class, well-educated Bengalis who came to the USA in the late 1960s to work in the medical and engineering professions or to teach in universities; their isolated lives with extended families made up of fellow Bengali expatriates; the customs and world view through which they see their own everyday experience; and the struggle of their "American" children with their own questions of identity and belonging. Unlike Bharati Mukherjee, another major diasporic Bengali writer based in the USA, who examines immigration and its attendant anxieties broadly from the standpoint of immigrants of various ethnic backgrounds, Lahiri's works exclusively chronicle Bengali-American's relationships to their "homeland" as well as their responses to immigration and assimilation. Lahiri does not write any elegy for diasporic condition; in fact, she does not equate the diaspora with the victim mode. Therefore, her fiction has none of the traumatic undertones of exile and forced dispersal associated with the JudeoHebraic origins of the word "diaspora." 7

In a typical Lahiri narrative, two generations of Bengali immigrants struggle to build secure and stable lives for themselves in an unaccustomed earth, accepting with excitement and anxiety the necessity of leaving behind the constrictions and comforts of the native way of life. The latest collection however - while it revisits similar set of characters engaged in negotiating conflicting values and loyalties - tends to lean more towards the experience of the second generation immigrants. Importantly therefore, compared to her previous works, it is little "less pronounced" about Bengali customs and

\footnotetext{
${ }^{5}$ Only the references to Lahiri's works are accommodated in the text by page number and shortened title; all the other citation details along with explanatory comments are provided in the footnotes. The following editions of Lahiri's books have been used for this purpose: Interpreter of Maladies. Boston: Houghton Miffin, 1999; The Namesake. Boston: Houghton Miffin, 2003; Unaccustomed Earth. New Delhi: Random House, 2008.

${ }^{6}$ In terms of geo-political nation-state, there is no longer an Undivided Bengal: the western part of what was earlier known as Bengal falls in the state of West Bengal in India; its Eastern part is now Bangladesh. However, while Bengalis are presently distributed among various geo-political boundaries casting them into different citizenships or awarding them hyphenated identities they are nevertheless "one" through the Bengali language and culture as well as a long shared history which transcends those borders.

${ }^{7}$ The Oxford Dictionary of English $(O D E)$ traces the origin of the word "diaspora" to Greek "diaspeirein" meaning "disperse" or "be scattered." The term was used in the Septuagint (Deuteronomy 28:25) in the sentence "ese diaspora en pasais basileis tes ges" which roughly means "thou shalt be a dispersion in all kingdoms of the earth." This is said to the Jews and till today, the primary meaning of "diaspora," as cited in $O D E$, is "the dispersion of the Jews beyond Israel." Robin Cohen notes that, with reference to the Jewish people diaspora signified "a collective trauma, a banishment. where one dreamed of home but lived in exile" (Glohal Diasporas: An lntroduction. Seattle: U of Washington Press, 1997. x). Also, see Neil Lazarus. The (ambridge Companion to Postcolonial Literature. Cambridge: CUP, 2004. 254-55.
} 
traditions; ${ }^{8}$ the shadows of Bengal fall on her characters' lives mostly through their parents' generation. And unlike Interpreter of Maladies, none of the stories in Unaccustomed Earth directly use Bengal as setting. ${ }^{9}$ However, references to Bengal keep cropping up either through the memory of the characters, or as a counterpoint to the "real," all-engulfing presence of the current home: "the characters must struggle and come to terms with what it means to live here [in America], to be brought up here, to belong and not belong here." 10 Lahiri's characters, as Michiko Kakutani says in his review of Unaccustomed Earth:

straddle two countries, two cultures, and belong fully to neither: too used to freedom to accept the rituals and conventions of home, and yet too steeped in tradition to embrace American mores fully ... she shows how some of the children learn to sidestep, even defy, their parents' wishes, yet how haunted they remain by the burden of their families' dreams and their awareness of their role in the generational process of Americanization. ${ }^{11}$

Unaccustomed Earth thus deals with pangs of displacement, processes of integration and accompanying loss of ("pure"/original) culture, and the quest for identity of the (second generation) Bengali immigrants. It is significant that, apart from the male perspective, Lahiri writes several stories from women's point of view and also draws on children in a number of her stories to unravel intricacies of the new generation's vision.

Significantly, Lahiri seeks to resist any idea that she is representing a group, ${ }^{12}$ she feels that being pigeonholed as an ethnic writer, being expected to be a spokesperson for the community can be stifling, and insists that she has never self-consciously tried to answer issues of identity. ${ }^{13}$ And for critics like Fakrul Alam, too, Lahiri has no specific thesis to illustrate about Asian Americans or immigration to America. ${ }^{14}$ Through his reading of her first collection Alam makes this point about Lahiri's handling of Asian Americans that she is not interested in issues of immigration, diasporas or cultural tensions per se, rather what she is centrally concerned about is the dynamics of human relationships in the context of diaspora: "While she has an eye for telling details about Indian culture and rituals, they are used as background to her major concern, people encountering each other." ${ }^{\prime 5}$ The majority

\footnotetext{
${ }^{8}$ Tasha Robinson. "Review of Unaccustomed Earth." op. cit.

"At least two of the nine stories of Interpreter of Maladies are set in Bengal and have no reference to America: "A Real Durwan" and "The Treatment of Bibi Haldar."

${ }^{10}$ Interview with Elizabeth Fransworth. 12 April 2000. 17 Aug. 2009. $<$ http://www.pbs.org/newshour/gergen/jan-june00/lahiri 4-12.html >.

"Michiko Kakutani. "Unaccustomed Earth". The New York Times. 6 April 2008. 31 Aug. 2009. $<$ http://everydayiwritethebook.typepad.com/books/2008/04/jumpa-lahiri-un.html $>$.

12 Alden Mudge. "Lahiri Probes Immigrant Identity in Her First Novel." Interview. 3 Sept. 2003. 3 Aug 2007. <http://www.bookpage.com/0309bp/jhumpa_lahiri.html > .

13. Interview with Gaiutra Bahadur. Citypaper.net. 16 Sept. 1999. 3 Aug. 2007. <http:// www.citypaper.net/articles/091699/feat.20q.shtml >

14 Fakrul Alam. "Representing Asian Americans in Short Fiction: The Stories of Bharati Mukherjee and Jhumpa Lahiri." Imperial Entanglements and Literature in English. Dhaka: writers" ink. 2007. 356-372. 363.

${ }^{15}$ ibid. 367-68.
} 
of the existing critical scholarship on Lahiri however identifies the author as a chronicler of Indian/Bengali-American lives and considers her fiction essentially as contributions to the literature of displacement. In fact, one can no longer see her protagonists as individuals so much as representatives of the diaspora, since they predominantly belong to a particular diasporic community. Her diasporics' continuous negotiations with the chaos/tension of multiple displacements - linguistic, cultural, geographical - together with their author's location in a privileged western metropolis essentially entangle Lahiri's narratives with the issues of representation and exoticisation, and invites comparison with other diasporic texts especially those of the South Asian authors. This paper therefore situates Lahiri's latest collection of stories in a larger context of the South Asian, more particularly Indian/Bengali diasporic writing, with a view to achieving a more nuanced and comprehensive perception of different facets of her politics of representation.

Since the $1970 \mathrm{~s}$, the phenomenon of expatriation, the state of immigrant communities in the West, the trauma of being uprooted, the diasporic consciousness, and the loss of "home" and resultant identity crises have preoccupied many South Asian writers, especially those that have opted to remain in the West. ${ }^{16}$ However, in no way can members of this "new" diaspora ${ }^{17}$ be considered as victims of any dispersal, nor do they entertain ideas of actual/physical returning. ${ }^{18}$ In fact, their leaving home almost amounts to an enactment of wish-fulfilment. Yet, as their movement is a cross-cultural or, in Makarand Paranjape's term, "cross-civilizational" passage, ${ }^{19}$ it involves a significant amount of tension between the source and the target cultures.

The people of Bengali origin are widely spread across the world; especially the 1960s witnessed the first massive surge of Bengali dispersion to different western metropolises. Not only do Bengalis comprise a sizeable diasporic group at present, but amid the wider phenomenon of South Asian English language writing, a discernable subset of fiction - marked by both the general traits it shares with the rest of the subcontinental literary diaspora as well as its peculiarly Bengali qualities $-{ }^{20}$ has been from probashi ${ }^{21}$

${ }^{16}$ Fakrul Alam. Introduction. South Asian Writers in English. Ed. Alam. Farmington Hills, Ml: Thomson Gale, 2006. xv-xxiii. xxii.

${ }^{17}$ In Vijay Mishra's words, this "new" diaspora is comprised not of indentured labourers but "economic migrants and refugees entering the metropolitan centres of the ex-Empire as well as the New World and Australasia" ("Diasporas and the Art of Impossible Mourning." In Diaspora: Theories, Histories, Texts. Ed. Makarand Paranjape. New Delhi: Indialog, 2001. 24-51. 26.)

${ }_{18}$ The classic definition of diaspora, based on the Jewish model, presumes that dispersal is due to forced exile from a homeland to which people essentially desire to return.

19 Makarand Paranjape. "Displaced Relations: Diasporas, Empires, Homelands." In Diaspora: Theories, Histories, Texts. op.cit. 1-14.6.

${ }^{20}$ This paper contradicts the homogenization of people from the subcontinent into a monolithic category called "Indian" from the inability to recognize cultural differences, as Adib Khan's Bengali protagonist in Seasonal Adjustments complains, "Everything from language to food, religion and accent has been moulded into a composition to fit a uniform view about an Indian" (St. Leonards, NSW: Allen \& Unwin, 1994. 144). Divakaruni rightly says, "A Bengali imnigrant is very different from a Kannada or a Punjabi immigrant" (qtd. in Gowri Ramnarayan. "In conversation with Divakaruni: Of gains and Losses." Hindı Literary Magazine 5 Nov. 2006: 3). And according to Rosemary Marangoly Gcorge, "all diasporas are not identical ... and as such deserve individual attention." See her essay. "At a Slight Angle to Reality: Reading Indian Diaspora Literature." Other Americans. Spec. issue of Melus 21.3 (1996): 179-193.179-80. 
Bengalis. Jhumpa Lahiri remains on the list of the obvious figures of this subset along with Bharati Mukherjee, Amitav Ghosh, Sunetra Gupta, Adib Khan, Chitra Banerjee Divakaruni, Monica Ali, Manzurul Islam, Tahmima Anam and others.

The experience of migration is context specific, and therefore it provides opportunities to compare and contrast the same community in diverse settings. The diasporic situation can be a fertile ground for translation of markers of ethnic identities. Ethnic groups wish to remain distinct, and consolidate and reaffirm their existence, identity any difference by means of symbols employed in their material culture (dress codes, food habits, form and content of education etc) and through non-material means (language and literature, religious beliefs, customs and habits, forms of address and modes of interpersonal behaviour, songs and myths, symbols and icons, history and tradition, life-style and sensitivities etc). While discussing different nuances of diasporic negotiations of ethnicities, Stuart Hall declines any possibility of fully retaining the original culture as well as any unproblematic assimilation into a host nation-state. He opines that diasporic cultural identity is characterised by hybridity, heterogeneity and the diasporic's endless transformation and transiation of self: "Diasporic identities are those which are constantly producing and reproducing themselves anew, through transformation and difference ..."22 The diasporic cultural space - fraught with contestations between the donor culture and the recipient culture - is the space that immigrants occupy almost perpetually since assimilation is an ongoing process and no full assimilation ever takes place. While trying to make necessary adjustments in this state of contestation between the two contending cultures, the diasporic individual becomes Janus-faced. And the expatriate authors like Lahiri tend to weave their tapestries from this two-tone yarns and textures.

Historically, Bengal has always existed as a distinct cultural formation within the Indian subcontinent embracing and synthesising various religious, spiritual and philosophical communities in the subcontinental social milieu. ${ }^{23}$ Bengalis are said to be very much aware of their own distinctive language and culture; and it is also attributed to them that they have got a kind of mental attitude which accepts external elements without renouncing its own individuality. This particular trait of the Bengali personality has been described by the great Bengali historian Nihar Ranjan Ray as baitasibritti - an interesting analogy connecting the essence of Bengali spirit to the resilience of cane plant. ${ }^{24}$ It is interesting to see that both the facets of this two-edged spirit - synthesizing as well as preserving, or co-existence of retentionist and integrationist tendencies - are at work in the diasporic context among Bengalis, as evidenced in Lahiri's works too. Interestingly, too, sometimes the sense of being Bengali in an expatriate has been stronger than the feeling amongst anasporic ${ }^{25}$ Bengalis.

\footnotetext{
${ }^{21}$ Meaning who lives away from home.

${ }^{22}$ Stuart Hall. "Cultural Identity and Diaspora." Colonial Discourse and Post-colonial Theor?: A Reader. Ed. Patrick Williams and Laura Chrisman. New York: Columbia U P, 1993. 392-403.401.

${ }^{23}$ Naila Kabeer. "The Quest for National Identity: Women, Islam and the State in Bangladesh." Feminist Review 37 (1991): 38-58. 39.

${ }^{24}$ Nihar Ranjan Ray. Bangaleer Itihas [History of Bengalis]. Kolkata: Dey's, 1996. 712.

${ }^{25}$ Fred W Riggs has coined this neologism as an antonym to diaspora; as he explains. "The stem for 'diaspora" is "speirein". meaning to scatter, and the prefix, "dia' means apart. The suffix an or ana means 'not' as in 'anachronism", 'analogy, 'anonymous" or 'anomaly.' We may therefore think of
} 
Lahiri's fiction touches upon the theme of Bengalis' cultural retentiveness and stresses their ethnic distinctiveness. In The Namesake, for example, Lahiri uses the Bengali practice of assigning two names ${ }^{26}$ to one individual as the central trope to foreground a distinctive cultural identity in the diasporic context. Her characters however do not seem to view culture as a frozen heritage, they do not deny it the life-breath of change and evolution. Thus her stories finally chart a slow but certain cultural shift from "purity" towards "hybridity." Lahiri's Bengalis recreate the experience they have left behind while simultaneously remake themselves and are reborn in the host culture. They exemplify Amitav Ghosh's argument that the South Asian diaspora is not so much oriented to roots in a specific place and a desire for return as around an ability to recreate a culture in diverse locations. ${ }^{27}$ The predominant feature of Safran's definition ${ }^{28}$ - the extensive emphasis on the connection with and return to the homeland - seems to be more applicable to the Jewish than the South Asian/Bengali diaspora.

Like other diasporas, the displaced and marginalised Bengalis also face problems of achieving a general cultural adjustment with the predominant foreign ethos together with an anxiety to come to terms with their own native heritage. Lahiri talks about the American culture of individualism as opposed to traditional Bengali culture of interdependence, familial protection and attachment. Her texts convey the conduct and behaviour of Bengalis, their lifestyle and sensitivities which are different from their counterparts in the West and other diasporic groups there. Their close-knit/ghettoised life, their festivities and $\operatorname{addas}^{29}$ seem to be some of the key agents which define their otherness. Another cluster of themes has to do with cross-cultural relationships and the condition of Bengali women as immigrants in the West. The stories of Unaccustomed Earth throw light on some of the core questions that concern the old and the new generation Bengalis in America: How does the sense of displacement felt by the older immigrants affect their America-born children? While trying to fit in with their American friends, how does the second generation negotiate with their connections to their heritage, their parents' way of life? And again, when they themselves become parents, how do they deal with issues of cultural identity in regard to their own sons/daughters? Lahiri's representation of a particular ethnicity in a specific diasporic location brings certain other relevant issues to the fore: how should Bengalis negotiate the present socio-cultural challenges and preserve their own tradition without becoming "ossified"? What are the consequences of refusing to make any compromise with, or of embracing western ideas and practices and tuming away from the ones that come here with them? And how does one draw the line between exoticism and writing ethnicity, or does Lahiri chronicle the community for the west? This paper attempts

those who have not scattered from home as being in anaspora." See his essay, "The Modernity of Ethnic Identity and Conflict." International Political Science Review 19.3 (1998): 269-288.286.

${ }^{26}$ The pet name/good name distinction in the Bengali nomenclature stands, in Lahiri's own words, as "almost too perfect a metaphor for the experience of growing up as the child of immigrants, having a divided identity, divided loyalties, etc" ("Jhumpa Lahiri on her Debut Novel - An Interview with the Author." Houghton Miffin. 12 Feb. 2010. $<$ http:/hinduism.about.com/library/weekly/extra/bljhumpainterview.htm>).

${ }^{27}$ qtd. in James Clifford. "Diasporas." Cultural Anthropology 9.3 (1994): 302-38. 306.

28 William Safran. "Diasporas in Modern Societies: Myths of Homeland and Return." Diaspora 1.1 (1991): 83-99. 83-84.

29 "Adda" refers to the culture of addictive, prolonged discursive sessions in Bengali social life. 
to offer some insights, principally through a critical perusal of Lahiri's latest book, into how Bengal and Bengalis figure in diasporic Bengali imagination and how the community negotiates its diasporic existence.

It is often assumed that the alienation and despair of first generation immigrants are more intense than those of the next generation who has seemingly fewer battles to fight; but The Namesake offers, through the bildungsroman of its second generation hero, Gogol a counterintuitive insight that this generation's sense of dislocation can be, in its own way, harder to deal with than the full-fledged transplantation traumas of the home-bred parent pioneers. In her new stories Lahiri has worked further on this theme. In the diasporic situation the parent-child relationship, understandably, is put to test not only because of adolescent angst and generation gap but also because of the challenge of living in diaspora. The children tend to question the relevance of the past to the present, of old and distant customs to the new and different environment while their parents fear the impending loss of their dearly nurtured original culture and identity. Yet, while due to the generation gap the migrants and their children inhabit dissimilar spaces in the host culture, their understanding of rootlessness and displacement can also be of parallel nature. In fact, both the generations' predicament, in their own peculiar ways, is like the predicament of Trishanku - trapped, wandering between two worlds/ subjectivities. ${ }^{30}$

The first generation tends to adhere to the traditional Bengali cultural protocol that is sensitive to taboos, less open to sexuality or alcoholism, protective about children, ${ }^{31}$ disdainful of western forms of individual liberalism, of public show of love and affection. Even among married Bengali couples love exists as "an utterly private, uncelebrated thing" (Namesake 138). The American child, Eliot in the story "Mrs. Sen's" discovers that the Sen couple do not "hold hands or put their arms around each other's waists" for photograph (Interpreter of Maladies, henceforth Maladies, 130). In "Hell-Heaven," Usha"s mother criticises Pranab's public gestures of affection to Deborah as a deviation from the Bengali culture; she tells the other Bengali women: "I don't understand how a person can change so suddenly. It's just hell-heaven, the difference" (Unaccustomed Earth, henceforth Earth. 69). Likewise, Sudha's parents in "Only Goodness" are "prudish about alcohol to the point of seeming Puritanical, frowning upon the members of their Bengali circle... who liked to sip whiskey at gatherings" (129). The Bengali parents are baffled by the children's individual assertion, their need to keep distance from the elders, their live-in relationships marks of their upbringing in a western society. Lahiri however does not forget that all members of the older generation are not alike. Amit in "A Choice of Accommodation" is stunned by his physician father's decision of returning "home" to join a Delhi hospital, because, his parents - unlike their uniformly successful crowd of Bengali friends in Massachusetts - had always been "dismissive, even critical, of India, never homesick or sentimental" and "his mother had short hair and wore trousers... His father kept a liquor cabinet and liked a gin and tonic before his meals" (Earth 95-96). Generally however, the

\footnotetext{
${ }^{30}$ Uma Parameswaran uses the mythical king Trishanku - trapped/suspended between heaven and earth - as the symbol of immigrant location. Members of diaspora, according to her, lead a Trishanku-like existence in a liminal world. See her essay. "Contextualising Diasporic Locations in Deepa Mehta's Fire and Srinibas Krishna's Masala." In Diaspora: Theories, Histories, Texts. op.cit. 290-300.292.

The narrator of "Once in a Lifetime." for instance. says: "My mother considered the idea of a child sleeping alone a cruel American practice" (Unaccustomed Earth 229).
} 
older generation Bengalis, in Lahiri's representation, remains to be a rather conservative community.

Although practically it is not possible for diasporics to continue with their native culture sans challenges any more, the first generation Bengalis try to recreate the ambience of their native land in the foreign soil. On the other hand, immigrant Bengali children try to underplay their ethnic identity and want to enjoy the freedom of American society. They are often so anxious to assimilate/acculturate that they hurt their parents in ways they scarcely recognise. Peer group pressures induce these adolescents to aggressively try to adopt American customs avoiding native ways and language of their parents as well as their parents' choice of food and dress. Lahiri recalls how much she resented the sense of "exclusion" being a Bengali child in America and appearing different from other children; she used to intensely feel "the need to just deny that we were different in any way, that our names were different, that we looked different, that our parents ate different stuff....[we] just want to be accepted by the people who are surrounding us." "32 The same sentiment is reflected in the character of Usha in "Hell-Heaven" when she gets furious with her mother for insisting her on wearing a shalwar kameez in the event of the Thanksgiving party at an American house (Deborah's): "I knew they [the Americans] assumed, from my clothing, that I had more in common with the other Bengalis than with them" (Earth 78). Obviously, this desire to act, dress or talk like any other Americans around them reflects the desire of these minority children to immerse themselves into the dominant culture. Born and brought up in America, they cannot really enter the emotional territory of their immigrant parents and cannot respond to their parents' cultural nostalgia, though ironically at the same time, they cannot escape that unlived, uncharted territory. Baffled by their parents' double standard and by the pressure of inhabiting a space between two cultures, never fully a part of the old or the new, the younger generation often grows defiant. Portraits of rebellious Bengali teens exemplified by Brick Lane's Shahana or Gogol in The Namesake are a regular appearance in diasporic Bengali narratives. Lahiri however believes that their behaviour is rebellious only in terms of peculiar Bengali standard of upbringing: "Neither Gogol nor I was terribly rebellious... But even ordinary things felt like a rebellion from my upbringing - what I ate, what I listened to, whom I befriended, what I read. Things my American friends' parents wouldn't think to remark upon were always remarked upon by mine." $\$ 3$

In the title story that opens Unaccustomed Earth, thirty-eight year old Ruma, who is trained as a lawyer, has recently moved from Brooklyn to suburban Seattle with her American husband and a three year old child. Her mother died suddenly the year before and she is now stressed about the presumed obligation to look after her father in her new home: Ruma fears "...it would mean an end to the family she'd created on her own" (Earth 7). Her individualistic American self comes into conflict with her inherited knowledge that as a Bengali child, she is expected to tell her father to come and live with her, more so when he is alone, a widowed old man. But then the father is also changed after so many years outside Bengal; and ironically, it is her father who does not want to be part of "another family" (no wonder, as her father reached her house and was coming out of the

\footnotetext{
32 "Intervicw: Jhumpa Lahiri." Filmiholic. 5 March 2007. 17 Aug. 2009. $<$ http:/filmiholic.com/2007/03/05/interview-jhumpa-lahiri>

33 "Jhumpa Lahiri on her Debut Novel - An Interview with the Author." Houghton Miffin. op. cit.
} 
car, Ruma was struck by the degree to which he "resembled an American in his old age" 11); he has elaborate plans of his own including a romance with a Bengali widow. Both father and daughter however avoid opening up their minds during his brief stay, and it is only after the father's departure that Ruma finds his letter to his lover.

The portrait of Akash in the story highlights the distance of the third generation diasporic Bengalis from their ancestral homeland and culture; in this particular case the distance widens further as the child is from a mixed marriage. Nevertheless, the Bengali grandfather feels in Akash "a direct biological connection, a sense of himself reconstituted in another; he sees "the continuance of his family beyond his death" (5I), the further strengthening of his roots in this unaccustomed earth. He is visiting their home for the first time in this new city, but instead of being detached and bored in the unfamiliar place, he reads to his grandson, clears the back yard, and plants a garden. The motif of garden is recurrently explored in immigration literatures across the world, perhaps because, as Robyn Corkhill says, "the garden is a symbol of nurture, for it creates a link between past and present, providing stability amid so much change." ${ }^{34}$ The suggestion is that the feeling of dislocation and insecurity that is so frequently a part of immigration experience can be overcome by virtue of a commitment to loving and working the soil of the adopted homeland. While tending the neglected garden, Ruma's father shows his grandson how to sow seeds in an uneven earth, clearly symbolic of their own existential struggle in that solitary land.

The migration separates the first generation expatriates from their homeland as well as from their own flesh and blood. In Ruma's house, while watching his grandson sleeping, the elderly Bengali visualises the toddler years from now shutting the door to his parents as his own children had done to him; he remembers "his children coming home from college, impatient with him and his wife, enamored of their newfound independence, always wanting to leave which had tormented his wife and had pained him as well" (54). To unravel the underlying tension and communication gap between Ruma and her father, Lahiri uses a dual perspective: she shifts throughout between Ruma's and her father's points of view. Besides, Ruma's mother, though dead before the story begins, has been very much present through reminiscences of her daughter and husband, and their memories of her also offer further insights into generational conflicts within Bengali families and other migrant issues.

First generation Bengalis like Ruma's parents attach great importance to retaining the Bengali language; they teach the children to read and write their "ancestral alphabet" (Namesake 66). Ruma's mother had been so strict in this regard that Ruma had never spoken to her in English. This linguistic nostalgia, in more subtle ways, haunts the second generation too. Ruma now finds herself wondering about the language and mores that her son inherits: "By now Akash had forgotten the little Bengali Ruma had taught him when he was little. After he started speaking in full sentences English had taken over, and she lacked the discipline to stick to Bengali.... Her own Bengali was slipping from her." (Earth 12). In spite of her efforts, Akash was turning into the sort of American child she was always careful not to be, "the sort that horrified and intimidated her mother" (23). In

3t Annette Robyn Corkhill. The Immigrant Experience in Australian Literature. Melbourne: Academia, 1995. 37. 
another early Lahiri story, "The Third and Final Continent" the Bengali parents make it a point to drive to Cambridge to visit his son or bring him home for weekends, so that "he can eat rice with us with his hands and speak in Bengali, things we sometimes worry he will no longer do after we die" (Maladies 197).

In Lahiri narratives, apart from language and rituals, food is of immense significance for the people trying to cope with life in a new world, so much so that Bengalis' staple diet, fish appears almost as protagonist in one Lahiri story ("Mrs. Sen's" in her debut collection). Lahiri represents food as metaphor for home and the connection between people. For Lahiri's Bengalis, as Asha Choubey points out, familiar items of food are as welcome as familiar faces in an alien land. ${ }^{35}$ Hema's mother in "Once in a Lifetime" cooks a big pot of khichuri typically when it rains (Earth 247). And in "Going Ashore," steaming rice, dense brown and yellow curries, whole red and green chillies floating in sauce reminded Koushik, "a little of his childhood" and "caused him to feel strangely sentimental" (325). For immigrant Bengalis food is thus linked with identity, serving as a slice of native life and inducing a sense of belonging in an otherwise alien world.

Apart from having these overlapping concerns with her earlier works, this new collection raises some issues which are hitherto unexplored in Lahiri's writings, issues that are especially sensitive for the usually conservative Bengali-American community. These include teen alcoholism which she attempts to explore in the story "Only Goodness." In this story, a sister eager to give her younger brother a "perfect American childhood" allowed him to join her in drinking adventures which eventually led the boy towards becoming an alcoholic. Sudha is now overwhelmed by guilt and anger when her brother's alcoholism tears up her childhood family and now threatens her own family. Their parents had always been "blind to the things that plagued their children in the foreign land... in their opinion their children were immune to the hardships and injustices they had left behind in India" (144). "Depression" was a foreign word, an American thing to the parents. Therefore, when Rahul slowly takes to alcohol and drops out of Cornell without finishing his studies, it is up to his sister, Sudha to confront him, since the parents would never know what to do in this situation. The lack of communication gap between parents and children in diaspora, in turn, often serves to strengthen bonds between siblings, bonds emerging out of a sense of being "fellow sufferers" facing similar bewilderment and confusion.

Excepting this alcoholic dropout brother, what the characters of "Only Goodness" have in common with others in this octet of stories is the fact that they all inhabit the elite rungs of North American society and tend to be uniformly successful, rendering Lahiri's representation almost homogenous, and consequently, limited/insulated. While Lahiri the "interpreter" displays a remarkable perceptiveness and an impressive eye for detail in describing the life and culture of Bengalis attempting to settle down in the USA, she could hardly go beyond a particular section (to which she herself belongs) of this community. Many of her characters are involved in inter-racial romances; they go to Harvard and expensive boarding schools; they study at Columbia's Butler Library and discuss Homer; they are doctors, engineers and academics apart from the Bengali housewives that is. Lahiri's characters, perhaps because of being educated and achievers in a society that

35 Asha Choubey, "Food Metaphor in Jhumpa Lahiri"s Interpreter of Maladies." 3 May 2003. 4 Oct. 20199. <http://www.scholars.nus.edu.sg/landow/post/ india/literature/choubey>. 
respects individual success and achievements, are generally shielded from racial discriminations, although exceptions have been pointed out in stories like "Only Goodness" where the children are reportedly "teased at school for the color of their skin or for the funny things their mother occasionally put into their lunch boxes" (143). While racial discriminations in the day-to-day diasporic existence is an inevitable topic to dwell on elaborately for many a diaspora narrative, in Lahiri texts this remains to be at best a fringe issue.

The anguish and frustration of the parents at their son's becoming an alcoholic and having been dropped from an Ivy League college in "Only Goodness" is reflective of the Bengali educated immigrants' view that education is a major, perhaps the only, means to climb social rungs and strike roots firmly in the adopted home. Various characters in the book epitomise the Bengali pride in education. Pranab in "Hell-Heaven," reportedly "a star at Jadavpur [university]" back in Bengal, is critical of American mediocrity: "These Americans are learning equations I knew at Usha's age" (63). Kaushik in "Once in a Lifetime" also mocks the common American's ignorance about the world (235). The Bengali parents expect their son or daughter to become distinctively educated and attain optimum success in their fields. This seems to be the overriding reason (and validation) for their coming to America. In the title story, Ruma knew that in spite of being a "good daughter," she had disappointed her father by getting rejected by all the Ivy League colleges she had applied for. And despite her brother Romi's itinerant, uncertain life, she knew her father respected him more for having graduated from Princeton and getting a Fulbright to go abroad. In "Only Goodness," too, as opposed to Rahul the failure, his sister Sudha belongs to the group of successful children, her collection of higher degrees framed and filling up their parents' upstairs hall (151).

Immigrant parents in Lahiri's stories of course appreciate the opportunity of raising their children in America; yet, they are suspicious and fearful about the alien culture and its influence upon their child. The conflict between academic and economic success in a foreign country and a lingering guilt-ridden conscience born out of having left their roots behind never fails to haunt them. This issue of loyalty and betrayal with regard to one's "own" culture is recurrent in Bengali diasporic narratives in general. In the title story of Unaccustomed Earth the elderly Bengali knows that he "had turned his back on his parents, by settling in America" (51). Ruma's mother also believes that her daughter intends to marry an American, because, she is "ashamed" of her origin (26). In "Hell-Heaven" Pranab's traditional Bengali father in Kolkata is horrified by the thought of his only son marrying a white; he would no longer acknowledge him as a son; and for his mother, too, this is clearly an act of "betrayal" (72). Besides, Pranab's absence in various Bengali gatherings was attributed by the members to Deborah, and it was universally agreed that this American woman had stripped him of his origins, and his example was invoked "as a warning, and as vindication, that mixed marriages were a doomed enterprise," reinforced by the fact that their two identical little girls barely looked Bengali and spoke only English and were not taken to Kolkata every summer (75). In "A Choice of Accommodations" Amit is aware that his Anglo wife is an "insult" to his parents (112). Again, in the title story, Ruma's mother tried to take Ruma out of marrying Adam saying that he would divorce her, that in the end he would want an American girl. Lahiri's ironic rebuffs of this self-complacent, prejudiced world-view of older Bengalis surface when the reader learns 
that in the incident of Pranab and Deborah's divorce, "it was he who had strayed, falling in love with a married Bengali woman" (81).

"Hell-Heaven," the relatively shorter piece of Unaccustomed Earth, narrativises Aparna's struggle to be adaptive to Boston and to her distant husband. The story is told in retrospect through the perspective of her young daughter Usha. Reminiscing her Boston childhood, Usha reflects on the intense cultural and emotional alienation that bewildered her young mother and led her to a tormenting, unrequited passion for a Bengali graduate student in Cambridge. The newly-arrived Pranab Chakraborty first saw her mother walking on a Boston street, and easily identified her as Bengali, because her mother was wearing the red and white bartgles unique to Bengali married women, and "a common Tangail sari." ${ }^{36}$ Besides, she had "the full round face and large dark eyes that are so typical of Bengali women" (61). Pranab Kaku" started to call her mother "Boudi"38 and transported her back to "the world she'd left behind in order to marry my father." Both of them happen to be from the same neighbourhood in North Kolkata and shared, like many other Bengalis, "a love of music, film, leftist politics, poetry" (64). Over the countless dinners she serves to Pranab, famished for proper Bengali meals, Boudi develops a lingering crush on this young student who eventually leaves her to marry his American beloved. Heartbroken Aparna could only attempt a non-materialised suicide.

At Bengali Pranab's wedding with American Deborah, Lahiri hints at clashes between cultures: when the guests were told to sit for dinner in an alternating boy-girl formation, Bengalis felt uncomfortable; and then Usha's father started to work "through his meal, his fork and knife occasionally squeaking against the surface of the china, because he was accustomed to eating with his hands"(78). Lahiri's narrative indulges here into rather clichéd details, reinforcing rather than challenging cultural stereotypes. Hirsh Sawhney in his review of Unaccustomed Earth is critical of such depictions which according to him are nothing but "a simplistic leftover from her previous work that enables her to spoon-feed western readers information about race and migration."

Lahiri's images of older generation Bengali women as rather confined creatures in this series of stories (in some stories they appear only fleetingly though) also serve to perpetuate negative stereotypes through which the average North American reader sees Indian life and culture in general; and subtly emphasise the diasporic location as a better place to live in, particularly for women. Bengali housewives like Aparna in "Hell-Heaven" or Chitra in "Year's End" are lonely, disempowered, and infused with notions of resignation and unquestioning suffering. They represent the values and world-view of first generation Bengali women who religiously conform to traditional norms and spend lives mainly as homemakers doting on their husbands and looking after their children. The native version of Bengali patriarchy is seen to proliferate in diaspora as well "as part of the

\footnotetext{
${ }^{36}$ Several of Lahiri's stories register Bengali women's fascination for saris, their adored traditional attire. Ruma's mother in the title story of Unaccustomed Earth laments over the fact that "her daughter preferred pants and skirts to the clothing she wore [saris], that there would be no one to whom to pass on her things" (17).

37 "Kaku" is an endearing way of addressing an uncle in Bengali.

38 "which is how Bengalis are supposed to address an older brother's wife" (Earth 60).

3i) Hirsh Sawhney. Review of Unaccustomed Earth. 7 June 2008. 13 Oct. 2009 $<$ http://www.guardian.co.uk/books/2008/jun/07/fictionl $>$.
} 
reproduction of structures at home." ${ }^{, 40}$ The first generation Bengali families in America retain their patriarchal divide of women's place and men's responsibility in a marriage. In "Year's End" Kaushik notices that his new stepmother "hovered over my father and me and the girls, eating privately after we were done" (268). Chitra behaves exactly the way she would have done in her native home back in Bengal, conforming to the pre-scripted role for the married woman in Bengali culture, the legacy of passive stoicism as prescribed through generations. Importantly however, despite complaints of "more solitude than [they] could bear" (29), Bengali women find reasons to celebrate their life in "unaccustomed earth" which, despite many inadequacies, offers them spaces for individual freedon and self-articulation, as Usha reflects, "Even in her bleakest hours of homesickness she [her mother] was grateful that my father had at least spared her a life in the stern house of her in-laws, in a suburb twenty mile outside Calcutta where she would have had to keep her head covered with the end of her sari at all times "(64). The diasporic space as an enabling site for women is however a common trope, particularly in female diasporic writings, as the fiction from Bharati Mukherjee, Monica Ali or Chitra Banerjee Divakaruni would testify. Mukherjee's fiction sees the USA as the land of choice and freedom for oppressed women from traditional cultures. ${ }^{41}$ Ali's Brick Lane too discards the memory-drenched golden image of home back in Bangladesh and celebrates the adaptability both of its immigrant protagonist, Nazneen as well as that of the multicultural metropolis, London which offers possibilities and rights to the Bengali women denied them in their mother country.

It is through the children that Lahiri's works illustrate the changing Bengali femininity. The second generation Bengali girls refuse to walk along their mothers" path; for Ruma "her mother's example - moving to a foreign place for the sake of marriage, caring exclusively for children and a household - had served as a warning, a path to avoid" (11). Unlike their mothers they are trying to carve out their own educational and professional trajectories on a par with their male counterparts. Ruma and her mother's perspectives - with regard to marriage, migration and identity issues - are opposite to each other epitomising further the distance between first and second generation Bengali women living in America. Lahiri's stories also show how diasporic situations affect the traditional institution of arranged marriage. The first generation Bengalis' conservative outlook regarding sex and marriage does not attract their children who prefer the "liberal" atmosphere of American society. Sexual liberation seems to have set them off on the route to assimilation - their coming to terms with the dominant culture. The traditional concept of the "sacrosanct" bond of matrimony does not hold much appeal for these Bengali children in the new world; that pressure has given way to "American commonsense" (Namesake 276). Also, Bengali parents' want their child to marry another Bengali, but the child does not see much sense in not marrying a white instead and consequently, the number of intermarriages is on the increase in the community.

Lahiri however does not come up with any serious, sustained debates around issues like politics of patriarchy in the community of Bengalis in America or gendered position of the Bengali immigrant women. In fact, there is nothing doctrinaire about her writing. Unlike

40 K. Satchidanandan. "That Third Space: Interrogating the Diasporic Paradign." In Diaspora: Theories. Histories, Texts. op.cit. 15-23. 20.

${ }^{+1}$ Inderpal Grewal. Transnational America: Feminisms, Diasporas, Nationalisms. Durham, N.C: Duke University Press, 2005. 79. Grewal is however critical of Lahiris position regarding this issue. 
Chitra Divakaruni, another Bengali diasporic author in the USA, Lahiri does not explore the cross-cultural experiences of diasporic Bengali womanhood through feminist perspectives. ${ }^{42}$ On the other side, Lahiri's male characters in Unaccustomed Earth like Koushik's father easily slip into being a typical Bengali male head of the family. They seem to fit into the category that G.S. Aurora calls "accommodationists." In their work-place, the accommodationists adopt the norms of the host society immersing themselves into the mainstream economic life while at home they try to preserve their original culture; this "adhocism" of adjustment allows them to preserve their cultural identity at home without it impinging in anyway on their economic goals. ${ }^{43}$ The conducts of Lahiri's Bengalis testify to this "uneasy co-existence of confident public identities with a tendency to ethnicize and privatize other aspects of their lives, including gender relations." 44

In several of her stories, including "Hell-Heaven," Lahiri deigns to furnish intricate anthropological footnotes in order to translate different facets of the life and culture of Bengalis to her predominantly western audience. Significantly therefore, untranslated Bengali words are sparse in Unaccustomed Earth while translated cultural details crowding the everyday chores of Bengali-Americans abound (clearly revealing her primary target, the white audience in America). The "exotic" institution of arranged marriage is not left out, nor are some rituals of the elaborate Bengali Hindu wedding and the festivities to be shared by the extended Bengali family. References to Bengal locales, Bengali names and phrases, Bengali customs and costumes, mannerism, attitude and upbringing, cooking and cuisine, literature, songs, films as well as sari-clad Bengali women, applying crushed vermillion to their hair jostle in her text.

The conducts of Bengalis abroad often blur the line between ghettoisation and selfassertion. Lahiri brings out the static quality which nostalgia confers upon a cocooned culture and the manner in which self-imposed ghettoisation interrupts the process of acceptance of / by the host culture. The young Bengalis strive to escape the constricting ghetto experience and aspire to become part of the mainstream through forging close

${ }^{42}$ Most of the eleven stories of Chitra Banerjee Divakaruni's first volume of short stories Arranged Marriage (1995), for example, are about immigrants in North America from the author's native region of Bengal and are told by female narrators mostly from professional classes. She talks about several immigrant brides in this collection who are, as Patricia Holt puts it," "both liberated and trapped by cultural changes," and struggling to carve out an identity of their own. See Holt's essay, "Women Feel Tug of Two Cultures." San Francisco Chronicle 1 Aug 1995: E5. Parameswaran also notes that Divakaruni "delves into the darker dreams and nightmares of womanscape and has an appreciative readership among feminists..." See her essay, "Home is Where Your Feet are and May your Heart be There Too!" Writers of the Indian Diaspora. Ed. Jasbir Jain. Jaipur: Rawat, 1998. 3239. 34.

43 Aurora qtd. in Indira Nityanandam. Jhumpa Lahiri: The Tale of the Diaspora. New Delhi: Creative Books, 2005. 82. Exposing this inherent ambivalence/hypocrisy in the immigrant parents' act of living in one spatial and cultural space but clinging to another Vijay Prashad notes, "In the U.S, desi sunders the world into two, the outside world, the world of workplace, is a world of capital that must be exploited as much as possible, and the inside world, the world of home, is a world of culture that must be protected and cherished." (The Karma of Brown Folks. Minneapolis: U of Minnesota Press, 2000.104).

${ }^{44}$ C. Vijayasree. "Survival as an Ethic: South Asian Immigrant Women's Writing." In Diaspora: Theories, Histories, rexts. op.cit. 130-40. 135. Vijayasree however said so in the context of Lahiri's first work The Interpreter of Maladies. 
relationships with the white. They cannot accept their parents' Bengali friends as their "honorary aunts and uncles," and also unlike their parents cannot believe in "befriending people not so much because they like them, but because of a past they happen to share" (Namesake 118). In fact, it is the second generation which plays the catalyst in drawing their parents to break away from the old mould into a more American lifestyle. Usha and her mother in "Hell-Heaven" finally make peace: "she had accepted the fact that I was not only her daughter but a child of America as well" (Earth 82). And over the years Ruma's mother also "retracted her objections" about her daughter's American husband (26). These negotiations register the slowly changing perspective of the older generation Bengalis who learn to become more accommodating and adaptive; they try to dismantle the rigid hold of the past in order to address the tension between assertion and assimilation. The single most prominent feature of diasporic literature, Victor Ramraj argues, is the conflict between fictional characters whom he classifies as assimilationists and traditionalists with authorial sympathy lying almost always with the assimilationists. ${ }^{45}$ This can be said of the writings of Lahiri as well as those of the other Bengali diasporic authors like Monica Ali or Bharati Mukherjee; all of them generally seem to discourage exclusivist/purist adherence to the native tradition, and espouse the need to assimilate and acculturate.

The second half of Unaccustomed Earth titled "Hema and Kaushik" presents a set of three intertwined stories - "Once in a Lifetime," "Year's End" and "Going Ashore" spanning the overlapping histories of the title characters. In the first two, Hema and Koushik addresses their stories to each other and explore a sense of belonging; their stories prepare for a much later, brief reunion, and subliminally a rupture as well which unfolds in the last, omnisciently narrated story. Hema and Kaushik meet first as children when their Bengali parents living in Cambridge, befriend one another; they meet again when they are teens and Kaushik's family return from India to stay temporarily with Hema's family till they find their own house. In the final story, Hema, now a thirty seven year old classics professor at Wellesley College on a sabbatical to Rome comes across once again her childhood acquaintance who has by then become a world-roving photojournalist. They involve in a passionate relationship despite the fact that Hema will go to Kolkata soon to submit to an arranged marriage.

The three stories embody in their structure and voices some of Lahiri's core themes. Kaushik, homeless at heart, tends to think "as a photographer, his origins were irrelevant"; his decision to become a photojournalist epitomises too, like Moushumi's opting for learning French in The Namesake, his search for a "third space," an alternative escape route from conflicting realities and subjectivities in diaspora. Yet, in spite of himself, he is practically overwhelmed seeing Hema again after a long break, as she was the only person he had met in his adult life "who had any understanding of his past" (Earth 326). Their meeting however does not reach a fairy-tale ending; instead, with Koushik perishing in the 2004 Asian Tsunami, it reaches a denouement that speaks of missed opportunities and avoidable grief and of a tie that seems preordained, rooted in a shared Bengali past.

\footnotetext{
${ }^{45}$ See Victor Ramraj, page 80, "Still Arriving: The Assimilationist Indo-Caribbean Experience of Marginality." Reworlding: The Literuture of the Indian Diaspora. Ed.Emmanuel S. Nelson. New York: Greenwood P, 1992. 77-86.
} 
A number of other issues that emerge from the reading of "Hema and Koushik" series are also worth noting. "My parents befriended people" Lahiri said, "simply for the fact that they were Bengali. There is this de facto assumption that they are going to get along, and often that cultural glue holds them." 46 This is mirrored by the friendship between the two sets of parents in "Once in a Lifetime." Despite differences in their social backgrounds back in Kolkata - the one hailing from a wealthy family who had summered in hill stations and attended expensive boarding schools, and the other being the daughter of a clerk in the General Post Office and having "neither eaten at a table nor sat on a commode before coming to America" (225) - Hema's and Koushik's mothers become instant friends, spending their days together while their husbands are at work. The diasporic situation indeed proves to be a great leveller; the differences of class, caste and wealth are blurred: "Those differences were irrelevant in Cambridge, where they were both equally alone..." (225). Hema's and Koushik's parents liked one another only for the sake of their common Bengali origins, for the sake of a time and place to which they lost access. The second generation point of view in this regard is embodied in Hema's revelation that she "had never been drawn to a person for that reason, until now" (315).

Some of the characters in the text have spent a part of their lives in Bengal and carried memories of their native life and culture offshore while others are bred since childhood outside Bengal and view their country only as an exotic place of origin. The former group has a literal displacement whereas the latter find themselves rootless. Home thus becomes unreal to the subsequent generations, "just a space of imagination rather than of nostalgic recollection," 47 not a place to return to, but a place to fantasise about, or may be to visit some time as a guest or a tourist. Indeed for characters in many South Asian Diaspora narratives "home" remains an intriguing, even elusive concept: often it is a lonely escape to an alternative reality from a defeated present, sometimes a bundle of betraying memories and longings, sometimes a wholly imagined idyllic hub and very rarely, a practically existing, cartographic space ready for return. In fact, when home becomes a series of mental images or a mythic space of desire, it automatically ceases to be a place of any real return; as the Indian-American poet Agha Shahid Ali's beautiful poem, "Postcard from Kashmir" describes how nostalgia purifies the poet's memory to fit the postcard image of the absent landscape so that home becomes no longer a topographical space but an arrested, idealized photographic moment, or in Sudesh Mishra's words, "an unattainable possibility." 48 In the "Introduction" to her short-story collection Darkness Bharati Mukherjee also refers to the "semi-assimilated" Indians with "sentimental attachments to a distant homeland but no real desire for permanent return." ${ }^{, 49}$ This diasporic (non-sincere) urge for return to the roots is humorously delineated as "Going Home Syndrome" in Ali's Brick Lane. ${ }^{50}$ Conforming to this dominant tone and trend, Lahiri's characters also do not seek a

\footnotetext{
${ }^{46}$ See her interview with Alden Mudge. op.cit.

${ }^{47}$ K. Satchidanandan. "That Third Space: Interrogating the Diasporic Paradigm." op.cit. 19.

${ }^{48}$ Sudesh Mishra. "From Sugar to Masala: Writing by the Indian Diaspora." An Illustrated Histon of Indian Literature in English. Ed. Arvind Krishna Mehrotra. Delhi: Permanent Black, 2003. 276294. 293.

${ }^{40}$ Bharati Mukherjee. Darkness. Harmondsworth, U K: Penguin, 1985. 3.

"In is interesting to see how Ali"s now-Londoner Bengali character, Dr. Azad defines the "Going Hone Syndrome": "This is another disease that afflicts us .. I l call it Going Home Syndrome ... I used to think all the time of going back ... Every year l thought, "Maybe this year." And l'd go for a visit,
} 
physical home back in Kolkata; they can offer Kolkata - like Sunetra Gupta's transnational characters in her second novel, Glassblower's Breath (1993) - only a "half-hearted courtship of nostalgia." $" 1$

Lahiri fuses this theme of migration and dislocation with that of individual relations. The stories of Unaccustomed Earth are replete with the sense of insecurity and uncertainty in personal human relationships against the backdrop of immigrant experience. The Bengalis' emotional struggles become metonymic of their diasporic existence. In other words, human relationships in these stories, in their anguish and sense of incompleteness, in their missed connections reflect the corresponding anxieties of Bengali diaspora in America, "its conflicts and exuberance, subtle tensions and quiet moments of happiness or pain." While discussing Lahiri's debut collection, O'Grady points out that Lahiri subtly employs human relationships in order to emphasise cross-cultural differences and convey information about dislocation and isolation in a new culture or lifestyle. ${ }^{53}$ In the domain of relationships, marriage is a recurrent trope in Lahiri's stories; the traditional Bengali system of marriage and family facing a different social structure provides the author the opportunity for delving into certain areas of cultural and generational clashes.

The Bengali immigrants construct a sense of community in their present social and cartographic reality where they see themselves as different by their original cultural legacies. The first generation strives to exist as "part of some makeshift extended Bengali family" (Namesake 204) in this kinless land. Lahiri's stories thus present a congregation of siblings, parents, spouses as well as relatives and acquaintances, and a compassionate inspection of the fissures, disappointments and importance of deep attachment. The text indicates the pattern of identity formation in the Bengali diaspora and the agencies involved in the construction of this identity which is essentially Bengali in content though recreated in form. In the stories the forging of new ethnic hybrid identities with particular reference to the second generation characters is part of a more general debate about American Bengalis and their sense of belonging. Being born in the USA, the children's acceptance of its culture is more spontaneous and enthusiastic; the culture of their country of origin naturally remains distant for them. They participate more actively in the wider social order than their parents. It is the children who question and redefine their own roles, rather than slipping into what is prescribed for them; they are more mobile in linguistic, religious and cultural terms. In Brick Lane, for Nazneen's daughters "home" is neither fantasy nor memory: Shahana can declare flatly, "I'm from London." ${ }^{54}$ Bengal is a cultural baggage of their parents, which they are unwilling to share. Many of Lahiri's characters also sprout from a new crossbreed culture and are nurtured in the Bengali-American awareness. In other words, her Bengalis come across new orientations to their originary culture as they negotiate between the foreign and the familiar to grow and be stable in diasporic life. While Lahiri's characters remain self-conscious of their ethnicity, and attempt to preserve their distinctive cultural traits, they cannot but participate in the host

buy some more land, see relatives and friends and make up my mind to return for good. But something would always happen... And I'd think, "Well, maybe not this year." And now, I don't know." (Monica Ali. Brick Lane. London: Doubleday, 2003. 24-25).

"Sunetra Gupta. Glassblower's Breath. London: Orion, 1993. 35.

${ }^{52}$ Rezaul Karim. "Jhumpa Lahiri." South Asian Writers in English. op.cit. 205-210.205.

Megan O'Grady. Review of Interpreter of Maladies. The Village Voice: 44.24 (1999): 104.

${ }^{5 t}$ Monica Ali. Brick Lane. op. cit. 245. 
culture through their professional engagements, personal relationships and raising families, highlighting the suggestion that salvation in the diaspora's disquiet journey lies in the acceptance of the inevitable existential ambivalence and negotiating accordingly. Lahiri thus writes about the characters navigating between the Bengali tradition they have inherited and the baffling new world they presently inhabit; and invites "a rethinking of the rewards and drawbacks of maintaining traditional ideas, beliefs and rituals of home for the diaspora." $" 55$

While the diasporic space provides writers like Lahiri with a unique point of view as outsider-insiders ${ }^{56}$ this space is problematic as well, especially from the perspective of reception where the culture of adoption wishes to see through the text the culture of the "other," while the culture of origin wants to assess the authenticity of self-reflection, ${ }^{57}$ and very often the writer is assailed for misrepresenting or catering to hegemonic market forces. The fact is, without the anthropological value which one automatically associates with minority representations in the West, the authenticity question would not have been so important or recurrent. Compared to the first generation diaspora writers like Bharati Mukherjee, Sunetra Gupta or Adib Khan, the next generation writers like Jhumpa Lahiri or Monica Ali are more frequently accused of their supposed lack of "the cultural ambidexterity" ${ }^{158}$ to write about Indian/Bengali characters and culture in an authentic way. ${ }^{59}$ Indeed, as the Pakistani-American writer Bapsi Sidhwa points out, it is not easy for the second generation, because of a diasporic upbringing, to portray the nuances of the culture back home and to get inside the skin of a character that is shaped by that culture. ${ }^{60}$ Lahiri is already a case in point: Calcutta is the place she is "taught" by her parents to call "home." Her experience of Bengal, according to her own admission, is "largely that of a tunnel, the

${ }^{55}$ Parmanand Jha. "Home and Abroad: Jhumpa Lahiri's Interpreter of Maladies." Indian Journal of English Studies 38 (2000-2001): 106-17. 106.

56" What was initially felt to be a curse" as Paul Gilroy has written, "the cause of homelessness or the cause of enforced exile-gets repossessed as a privileged standpoint from which certain useful and critical perceptions about the modern world become more likely" ((Against Race: Imagining Political Culture Beyond the Color Line. Cambridge: Harvard U P, 2000. 111). Rushdie too believes that "however ambiguous and shifting this ground may be, it is not an infertile territory for a writer to occupy. If literature is in part the business of finding new angles at which to enter reality, then once again our distance, our long geographical perspective, may provide us with such angles" (Imaginary Homelands. London: Granta, 1991.15).

${ }^{57}$ The work of a diasporic writer, as Jasbir Jain explains, attracts the attention of two different sets of readers - the west looks for familiar landmarks, a west-centric vision, while the reader at home seeks his own validity ("The New Parochialism: Homeland in the Writing of the Indian Diaspora." In Diaspora: Theories, Histories, Texts. op.cit .79-92. 85).

${ }^{58}$ Lahiri's own phrase from her essay, "My Intimate Alien." Stree [Woman]. Spec. issue of Outlook (2000):116-20. 118 .

${ }^{59}$ The politics of right to write is indeed intriguing. Rushdie disowns licensing authorities in his defence, and emphasizes that literature is self-validating; "a book is not justified by its author's worthiness to write it, but by the quality of what has been written ... Literature is not the business of copyrighting certain themes for certain groups" (Imaginary Homelands. op.cit. 14). The point is, like any other writer, the diasporic author also owns the right to speak of any subaltern of her choice.

(x) Sidhwa qtd in Jaydeep Sarangi. "The Enigma of Cultural Multiplicity: A Study of Interpreter of Maladies." Jhumpa Lahiri the Master Stonteller. Ed. Suman Bala. New Delhi: Khosla, 2002. 229237. 235. 
tunnel imposed by a single city [Calcutta] we ever visited, by the handful of homes we stayed in, by the fact that I was not allowed to explore the city on my own." ${ }^{61}$ In "Once in a Lifetime," her character Hema indeed exemplifies her emotion when she (Hema) recalls Kolkata "which she'd visited throughout childhood" as a city "she knew on the one hand immediately and on the other hand not at all - a place that fully absorbed her and also kept her at bay" (Earth 299).

Because of this distance from and inadequate knowledge and experience of original geographical and cultural scapes, Lahiri's narratives tend to indulge at times in pre-existing white stereotypes of eastern idiosyncrasies and the fetishized symbols of the eastern culture. And this ensures her entry - voluntary or unconscious - in the hegemonic niche market in the West for fictional representation of exotic ethnicity. ${ }^{6.2}$ The promotion of the diasporic writer as being the local expert of his/her respective ethnicity is integral to the politics of this hegemonic publishing industry thriving on the commodification of an exoticised East. Critics like Somdatta Mandal however wants to believe that Lahiri does not intend to flaunt that "exotic" factor and that her fiction transcends mere ethnic exoticism. ${ }^{63}$ Another critic, Mandira Sen, in her review of The Namesake finds Lahiri's novel to be "as different as it can be from the exotic outpourings of Indian immigrants writing in English." ${ }^{164}$ It remains indeed difficult however to single out Lahiri's fiction from those immigrant writings for which "home" provides only a convenient canvas for "magical interpretations" in order to "spoonfeed" readers with racial information. References to the native locales or cultural elements lend Lahiri's fiction anthropological glamour, and provide her with a "device" to woo her (non-Indian) audiences with exotica.

According to Sunetra Gupta, this exoticisation of homeland characterises much of the contemporary Indian diasporic writing in English: "I think there is quite a bit of writing that does exploit the current market which I liken to the big travel market that we have now .. .65 Gupta resents the fact that "a readership is being created by offering them exotic tidbits to titillate them." ${ }^{66}$ Lahiri becomes essentially entangled in the politics of this hegemonic literary market - which Gupta derogatorily labels as "travel market" - as her characters appear to retain sufficient Bengaliness to be exotic while they float gleefully into "American materialism."

61 “My Intimate Alien." op.cit. 117-18.

62 Another London-based Bengali author, Neel Mukherjee recalls his experience with one UK publisher (he approached her for his debut novel, Past Continuous, 2008) who wanted him to turn the novel "into a fluffy, romantic, weepy Exotica Fest"; she desired that he include more of India's "heat and dust," "smells and colours" (Aditya Sudarshan. "Exile as a Choice." Interview with Neel Mukherjee. Hindu Literary Review 6 Sept. 2009:1).

${ }^{63}$ Somdatta Mandal. "Of Defining and Re-Defining the Asian-American Diaspora: A Case Study of Jhumpa Lahiri." Jhumpa Lahiri the Master Storyteller. op.cit.17-32. 28.

${ }^{64}$ Mandira Sen. "Names and Nicknames." Review of The Namesake. Women's Review of Books 21.6 (2004): 9-10. 10.

${ }^{65}$ Ghosh Ranjan and Christiane Scholte. “... nobody likes to be bracketed." Interview with Sunetra Gupta. Critical Practice 11.2 (2004): 117-124.

(6) Interview with rediff.com. "A Readership is being Created by Offering Exotic Tid-Bits to Titillate Them." 21 Feb 1996. 10 Oct. 2009. <http://www.rediff.com/news/feb/ 2 l women.htm>.

"Malashri Lal suggests in a discussion of Mukherjee's novel Jasmine (1989) that "Mukherjee has made up a formula which apparently works - Indian characters in search of American citizenship 
It is really intriguing however as to where to draw the line between exoticisation and writing ethnicity. Because, one can still argue that if Lahiri's writings at all parricipate in the politics of exoticised oriental, then it is only by default (due to her dealings with a cultural milieu not very familiar with western readership). Perhaps following the Rushdiean analogy of archaeological survey where even pieces of the most quotidian objects are exciting discoveries to reconstruct a past, ${ }^{68}$ Lahiri refers to even tiny fragments of a culture as significant symbols in her projection of the Bengali life and ethos. As Lahiri's engagement with the culture back home is not intense and prolonged, it only gets at times benignly parodied in the rather simplistic, fragmentary and clichéd anthropological details, as is the custom with many a diaspora home-narrative. Lahiri's representation of Bengal and Bengalis therefore cannot claim to be a very useful interrogation into this particular culture and humanscape. The repetitive appearance of the same cultural troop (some representative icons, rituals and festivities, e.g. annaprasan or the rice ceremony, intricate skein of kinship, fish, sari etc.) in her stories proves to be a rather futile attempt at any deep and inclusive evocation of the Bengali life and ethos, or at conveying the impression of familiarity with Kolkata's "heat and dust, smells and colours." This painstaking attempt at verisimilitude betrays Lahiri's anxiety about authenticity too ${ }^{69}$ Unlike many other writers like Monica Ali or Adib Khan, Lahiri however is never overtly critical of Bengalis, rather, like Sunetra Gupta, her treatment is more sympathetic and nostalgic than judgemental. In spite of the slightly ironic tone pervading the Lahiri narratives, the final impression is that of an obsession with and a personal admiration for Bengali tradition and culture.

In his "Introduction" to South Asian Writers in English (2006) Fakrul Alam observes that some of the South Asian authors celebrate "cultural hybridity and the energy of new immigrants." enthusiasm are almost defining tones of their narratives. Bharati Mukherjee, for example, redefines the idea of diaspora as a process of gain. In a 1988 interview to Massachusetts Review, Mukherjee rejected Naipaul's bleak vision of the immigrant experience; ${ }^{71}$ and in the stories of Darkness too, she celebrates her own transformation "from the aloofness of

retain sufficient Indianness to be exotic but float gleefully into American materialism" (qtd. in Radha Chakrabarty. "Bharati Mukherjee." South Asian Writers in English. op.cit. 242-251. 249). What Lal said about Mukherjee's characters can be applied to those of Lahiri too.

${ }^{68}$ Rushdie explains, "I am not gifted with total recall, and it was precisely, the partial nature of these memories, their fragmentation, that made them so evocative for me. The shards of memory acquired greater status, greater resonance, because they were remains; fragmentation made trivial things seem like symbols...There is an obvious parallel here with archaeology. The broken pots of antiquity, from which the past can sometimes, but always provincially, be constructed, are exciting to discover, even if they are pieces of the most quotidian objects..." (Imaginary Homelands. op.cit.12).

${ }^{69}$ The authenticity debate however is an old and recurrent one, and of course, has not spared even the latest Booker prize winner from India, Aravind Adiga's debut novel, The White Tiger (2008). Its depiction of a filthy, greedy and poverty-stricken life in the Bihari hinterland of India has been criticized by novelist-critics like Amitava Kumar, who accuse it of being "curiously inauthentic," "a novel from one more outsider, presenting cynical anthropologies to an audience that is not Indian" ("On Adiga's The White Tiger." The Hindu Literary Review' 2 Nov. 2008: 7).

\footnotetext{
${ }^{70}$ Fakrul Alam. Introduction. South Asian Writers in English. op.cit. xv-xxiii. xxii.

${ }^{7}$ Alison B. Carb. "An Interview with Bharati Mukherjee." Massachusetts Review' 29.4 (1998): $645-54$.
} 
expatriation, to the exuberance of immigration." 72 Conforming to this dominant tone and trend, Lahiri also captures the trials and tribulations as well as the zest for survival and ingenuous modes of self-refashioning of the Bengali immigrants in America. Lahiriesque fictional characters tend to advertise their diasporic lives and identities as a success-story, iconised by this Bengali gentleman of Lahiri's "The Third and the Final Continent" who emigrates from Calcutta to London, and finally makes Boston his home and conclude that his survival on three continents is as momentous as the landing of the American cosmonauts on the moon (Maladies 198). In other words, the life of even an ordinary Bengali who has settled down in America is itself an extraordinary event. Lahiri's Ashima, in a moment of intense desolation, may describe the expatriate situation as "a sort of life long pregnancy -- a perpetual wait, a constant burden, a continuous feeling of out of sorts" (Namesake 49), but this is not at all the defining tone of Lahiri narratives; even the same Ashima finally learns to love the USA and divides her time between "two homes" after her husband's death when she could have settled down in Kolkata.

According to Mukherjee, the immigrants, impatient to establish themselves and rejecting self-effacement, are re-shaping American culture. ${ }^{73}$ Her reconceptualisation of American multiculturalism resonates with Homi Bhabha's "third space" of cultural production within which different elements encounter and transform one another. Such negotiation, Bhabha explains, is neither assimilation nor collaboration, but makes possible the movement of meaning within the dominant culture. ${ }^{74}$ There are no efforts, at least overtly, in Lahiri's Unaccustomed Earth to articulate any such thesis inculcating this twoway process of cultural interchange/interaction; rather, for Lahiri, it remains to be one-way: only the Bengalis seem to be changing. Lahiri is different from Mukherjee in other ways too: no Lahiri story, in attempting to capture pressures of immigrant existence, culminates into such bizarre and violent ends as it occurs in Mukherjee's second novel, Wife (1975) where a Bengali housewife in New York eventually kills her husband, or as in another Mukherjee story, "A Father" from Darkness (1985) where an enraged Bengali father in Detroit attacks his Americanised daughter who impregnates herself through a sperm bank. Nor does Lahiri deal with lives of any illegal/fugitive immigrant characters in her fiction.

Lahiri's own diasporic trajectory offers insights into her personal views regarding representation, diasporic anxieties, generational conflicts and identity politics. Born in London, raised in Rhode Island, and taken on regular visits to Kolkata, Lahiri grew up in the midst of "conflicting expectations" which she felt to be in direct opposition to the present reality, the expectation of her American peers to become like them, and her own expectation to fit herself into American society. ${ }^{76}$ The characters in the latest Lahiri collection are likewise involved in their own struggles for striking roots into an unaccustomed earth strewn with conflicting expectations, affiliations and loyalties. Especially in the title story, and in the three linked

${ }^{72}$ Darkness. op.cit. 3.

73 Bharati Mukherjee. "Immigrant Writing: Give Us Your Maximalists!" New York Times Book Review. 28 Aug. 1988: 28-29.

${ }^{74}$ Bhabha. Homi. "Culture's in-between." Questions of Cultural Identity. Eds. Stuart Hall and P. du Gay. London: Sage, 1996. 53-60. 58.

75 "One of the things I was always aware of growing up was the conflicting expectations," Lahiri said in an interview with Gaiutra Bahadur. op.cit.

${ }^{76}$ Interview with Elizabeth Fransworth. op.cit. 
stories that close the collection, she maps the divergent angles of vision and emotion that obstruct, even as they broaden, her characters' search for a sense of belonging. Lahiri's narratives however do not provide any answer prescriptively as to how Bengalis are to live their diasporic reality, instead, by depicting the characters' attempts to cope with the chaos of multiple displacements and generational conflicts, she proposes to offer a complex look into the issues. On the one hand, there is awareness of diaspora as a condition of loss and longing and on the other, there is acknowledgement of it as a condition of gain or "rehousement," of recreation and regeneration in a new spatial and socio-cultural scapes. Lahiri's fiction thus projects diasporic location to be a mixed blessing: it remains to be such a home that engages one in continuous negotiations, and offers its unique challenges as well as possibilities. Rejecting any bleak vision of immigrant experience, her narratives epitomise both anxieties and excitements of the characters in the new land. Lahiri's texts generally suggest, in opposition to the adoption of a ghetto mentality, the need to assimilate/ acculturate and not to complicate things too much through continuous nostalgic returns to the old world. Thus finally, her representation of diaspora appears to foreground positive transformative potentials of immigration, and the readers who come to her stories looking for the anxiety of displacement often turn away disappointed.

In a general discussion ${ }^{77}$ on Indian diasporic literature M K. Naik and Shyamala A. Narayan referred to Jhumpa Lahiri among others and complained that her narratives "sometimes ring a false note when describing the Indian milieu." Lahiri herself admits (although she wants to believe that her images of Bengal and Bengalis manage to evoke at least "for some readers and reviewers, here and there, the illusion of cultural accuracy and resonance" ${ }^{178}$ ) that her knowledge of "home" is limited not only by her own lack of proximity but by the fact that the principal resource of her knowledge - her parents' impressions of their native land and culture - has also been arrested in time. ${ }^{79}$ But then of course Lahiri has a first hand experience of "unaccustomed earth," and she is presenting just a personal vision of what she thinks to be true about the Bengali diaspora in America, just one angle of looking at it.

\section{A. F. M. MASWOOD AKHTER}

See for detail, M K. Naik and Shyamala A. Narayan. Indian English Literature 1980-2000: A Critical Survey. Delhi: Pencraft International, 2001. 106, 139.

78 "My Intimate Alien." op.cit. 118. 